\title{
3D Visualization of Bone Structure and Thickness
}

\author{
Mihails Kovalovs ${ }^{1}$, Aleksandrs Glazs ${ }^{2},{ }^{1,2}$ Riga Technical University
}

\begin{abstract}
In this paper authors propose a method of bone structure 3D visualization is proposed, which is based on medical images and can separately visualize the cortical and trabecular bone. To visualize the bone structure, the cortical and trabecular bones are first extracted from the medical images using fully automatic image processing methods. The proposed method could be used when analyzing the medical images of patients with osteoporosis, where it is necessary to analyze changes in the microstructure of the bone.
\end{abstract}

Keywords-Cortical bone, medical images, segmentation, trabecular bone, visualization.

\section{INTRODUCTION}

Bone structure analysis is necessary, when determining the bone strength and measuring the bone micro architecture deterioration, which happens as a result of such bone disease as osteoporosis. Bone structure analysis of a living person (in vivo) is easier and more effective to perform by using medical images. Traditionally, medical image analysis is performed by a radiologist, who visually looks through all two-dimensional images that are divided into slices. Such analysis is subjective and takes a considerable amount of time. To speed up the analysis and to acquire reproducible measurements, it is useful to apply computer and automatic medical image processing methods. Bone structure analysis can be further improved by using bone structure three-dimensional visualization.

There are two major kinds of bone, cortical and trabecular (Fig. 1). The hard outer layer of bones is composed of cortical bone tissue. This tissue gives bones their smooth, white and solid appearance, and accounts for $80 \%$ of the total bone mass of an adult skeleton. Filling the interior of the bone is the trabecular bone tissue (an open cell porous network also called cancellous or spongy bone), which is composed of a network of rod- and plate-like elements that make the overall organ lighter and allow room for blood vessels and marrow. Trabecular bone accounts for the remaining $20 \%$ of total bone mass but has nearly ten times the surface area of compact bone. The trabecular bone is usually found at the end of long bones and inside the vertebra.

Osteoporosis is a bone disease in which bones become brittle and fragile from the loss of tissue, typically as a result of hormonal changes, or deficiency of calcium or vitamin D. At present osteoporosis is mostly diagnosed by measuring the bone mineral density (BMD), which is usually obtained using dual-energy x-ray absorptiometry (DXA) [1]. DXA is a two-dimensional, projection-based radiographic technique that measures integral BMD of both cortical and trabecular bone. BMD only explains about $70 \%$ to $75 \%$ of the variance in bone strength [2], while the remaining variance is due to the cumulative and synergistic effect of other factors such as bone architecture, tissue composition and micro damage [3]-[5].

In recent years there has been an increased interest in developing techniques to analyze medical image to evaluate bone microstructure [6], [7]. Most of these techniques use medical images, which have been acquired by high resolution computed tomography [8], [9] and magnetic resonance imaging tools [10], [11], that are fairly expensive and not available in most clinics.

\section{II.PROPOSED METHOD}

In this paper a method of bone structure $3 \mathrm{D}$ visualization is proposed, that can separately visualize the cortical bone and the trabecular bone. This method uses medical images that have been acquired using conventional computed tomography. It automatically extracts the trabecular and cortical bone from the image and can also visualize bone thickness by displaying the $3 \mathrm{D}$ model in different color, where the colors represent different thicknesses.

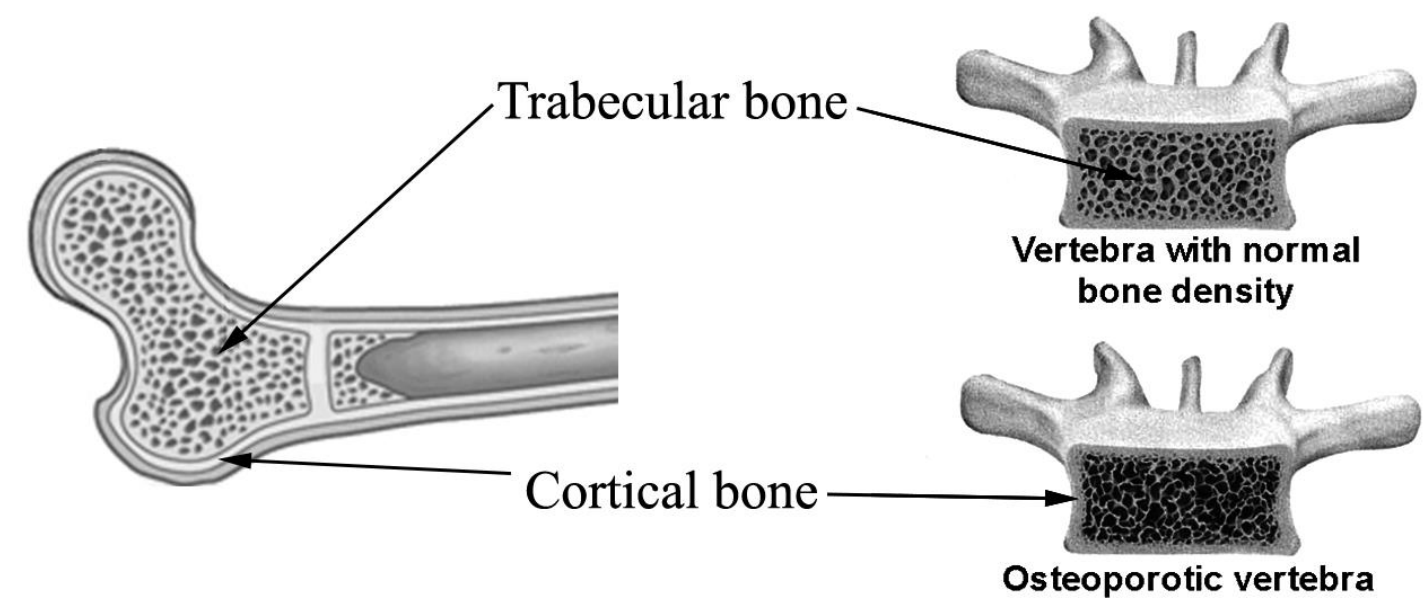

Fig. 1. Different bone types. Left: long bone. Right: human vertebra. 
The proposed method consists of three steps: cortical bone extraction, trabecular bone extraction and bone structure visualization.

\section{A. Cortical Bone Extraction}

The cortical bone extraction algorithm starts with the medical image segmentation, where the medical image is divided into segments, which might contain the cortical bone. This part of the algorithm is the same for the medical images of the vertebra and long bones.

The medical image segmentation algorithm uses one of the properties of computed tomography, where each pixel of the medical image contains information about the density of the matter [12], [13]. Due to this property it is possible to extract the cortical bone from the image by using a threshold. The threshold of the cortical bone could be defined by using the Hounsfield scale [14], which provides a scale of matter based on their radiodensity. By using this scale it is possible to set the threshold that can be used to find all pixels, whose density matches that of the cortical bone and to remove all the remaining pixels from the image, leaving only the cortical bone.

But not all pixels whose density falls into the threshold of the cortical bone are actually the cortical bone as seen in Fig. 2b), so in the next steps it is necessary to find those pixels that actually contain the cortical bone and to remove all the rest.

Another problem that might appear is related to the porosity and holes that develop inside the cortical bone due to osteoporosis. Because of that the cortical bone might consist of several parts on the image, which makes the next step of the algorithm more difficult, where all pixels are grouped into clusters. To solve this problem the density threshold is expanded to include the matter, whose density is close to that of the cortical bone, thus extracting a larger and more interconnected region from the medical image shown in Fig. 2b).
The clustering process takes all of the previously extracted pixels and groups them into clusters based on the proximity between the pixels by using a region growing algorithm [15].

When the image is divided into clusters, the segmentation threshold is returned back to the cortical bone density, thus leaving only the pixels that might contain the cortical bone and preserving the assigned clusters, as shown in Fig. 2d). The clusters that contain a small amount of pixels are also removed from the image.

In the next step the clusters are classified to find those clusters that contain the cortical bone and to remove all other clusters. This step differs between the images of the vertebra and the long bones, because in each case it is necessary to find a different amount of cluster: one in the case of the vertebra and two or four in the case of long bones (legs).

When classifying the clusters from the medical image of legs, it is necessary to find two or four clusters that contain the cortical bone. All clusters are analyzed in pairs to find a pair that fits the three requirements: shape, location and proportions. All possible combinations of pairs are considered and in the end those pairs that fit the requirements are classified as cortical bones.

The classification of clusters from the medical image of the vertebra is relatively simple, compared to the classification of the leg cluster, because in this case we are looking only for one cluster that contains the cortical bone of the vertebra, which is usually located at the center of the medical image. So here it is only necessary to locate the largest cluster which is closest to the center of the image. When this cluster is found it is classified as a cortical bone.

After the classification process is complete, all the clusters that are not classified as cortical bones are removed from the medical image, as seen in Fig. 2d), thus concluding the cortical bone extraction.

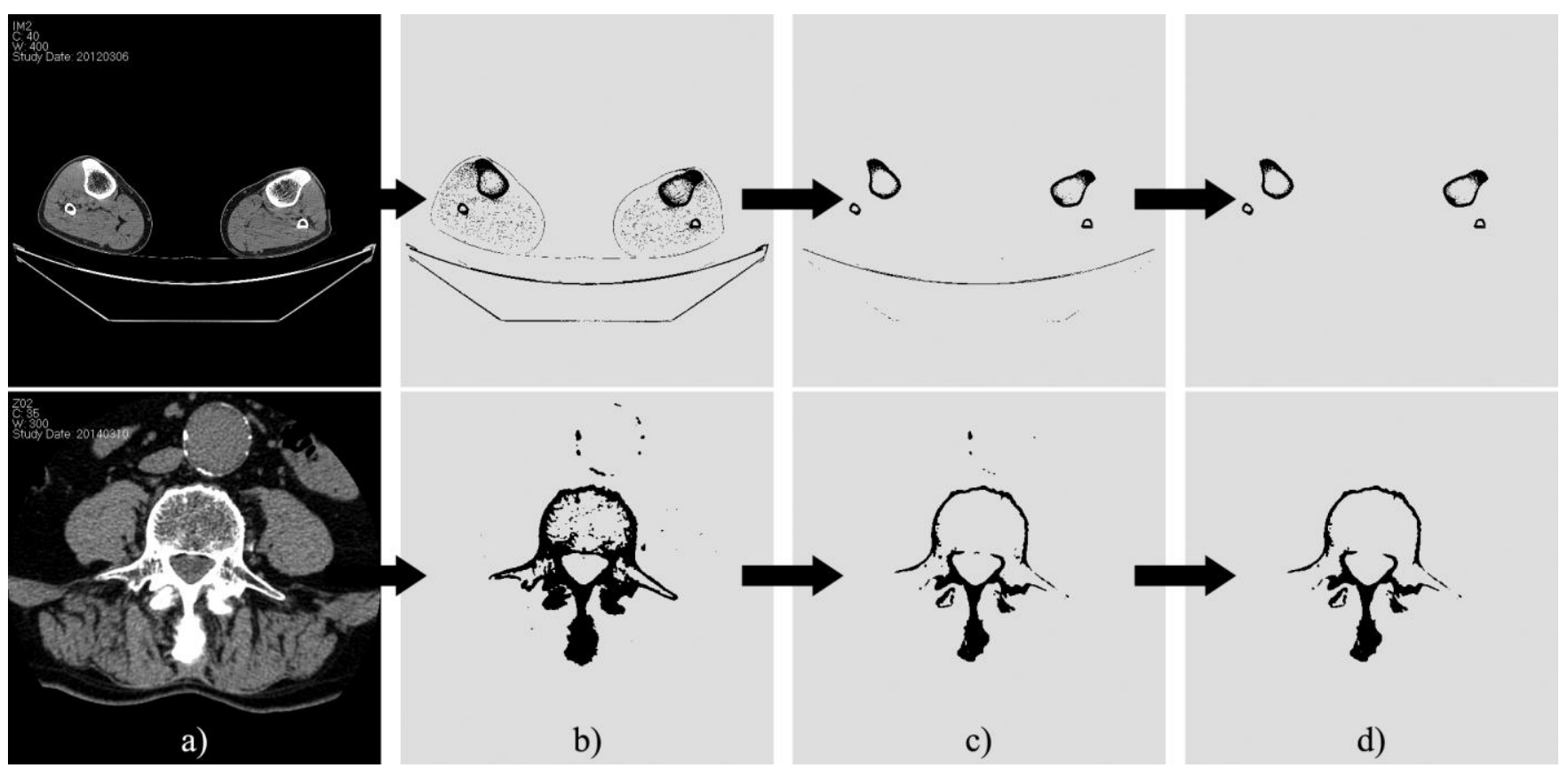

Fig. 2. Cortical bone extraction. Top: long bones (legs). Bottom: vertebra: a) original medical image; b) medical image segmentation; c) clustering and shrinking the segmentation threshold; d) extracted cortical bones. 


\section{B. Trabecular Bone Extraction}

Trabecular bone is extracted by using the previously extracted cortical bone and by creating a contour inside it that adapts to the inner edges of the cortical bone, thus defining the region that contains the trabecular bone, which is located inside the cortical bone.

This contour is necessary because it is not always possible to extract the trabecular region by using some kind of region growing algorithm, due to the holes that might appear on the cortical bone, and the region growing algorithm might escape through these holes out of the cortical bone. So it is necessary to create a contour which adapts to the inner edge of the cortical bone and ignores the holes.

Before the adaptive contour can be created a general contour is created, that is used to define a border, which the adaptive contour cannot pass. This general contour is created by finding the pixels whose density value changes from the positive into negative, thus roughly defining everything outside the cortical bone.

The adaptive contour creation starts by selecting the starting point, which is located at the center of the cortical bone. The starting point selection algorithm of the medical images of long legs and of the vertebra differs, because the shapes of the cortical bones are different.

In the case of the long bones, the starting point selection is rather simple, because the shape of the cortical bone of a long bone is somewhat round and the starting point is always in the middle. So, to calculate the coordinates of the starting point, it is necessary to find minimal and maximal coordinates of the pixels belonging to the cortical bone on the $x$ and $y$ axis, and the coordinates of the starting point will be a mean value between the minimal and maximal coordinates.

The starting point selection for the images of the vertebra is considerably more complicated, compared to the long bones, because their shapes are very different and the middle point cannot be set as a starting point, since it usually falls inside the cortical bone. So the selection of the starting point for images of the vertebra is a longer process and contains several steps:

1. The cortical bone is fitted inside a rectangle;

2. The $y$ coordinate of the starting point is selected as a middle point of the upper half of the rectangle created in Step 1;

3. The $x$ coordinate is calculated as a mean coordinate of all the coordinates of the left and right borders of the cortical bone inside the upper half of the rectangle created in Step 1.

After the starting point is selected, the adaptive contour creating algorithm is the same for the vertebra and for the long bone case. The main idea behind the creation of the adaptive contour is that, the control points are placed at the starting point, which then move in all directions until they reach the cortical bone, thus adapting to the inner edge of the cortical bone. This algorithm contains several steps:

1. Four control points are placed at the starting point and for each control point a movement vector is set, where each vector points in different direction (up, right, down, left), as shown in Fig. 3a);

2. Each control point moves by one pixel at a time in the direction of its vector, the control point stops if after moving it is located on the cortical bone or the general contour;

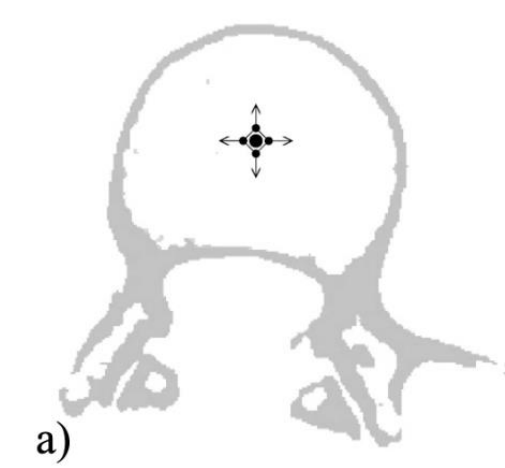

a)

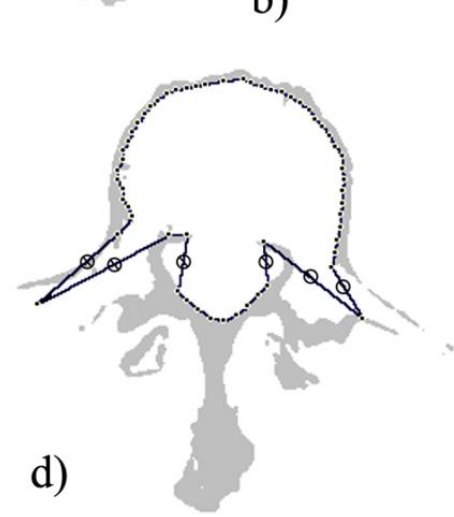

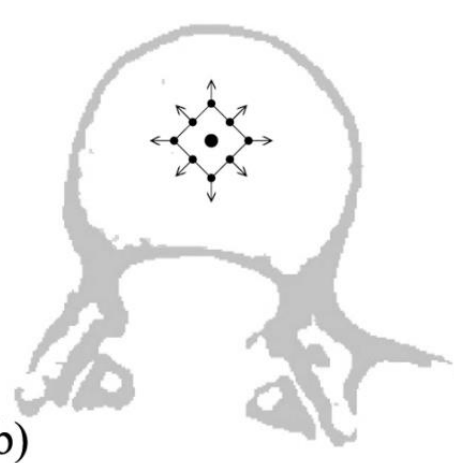

c)
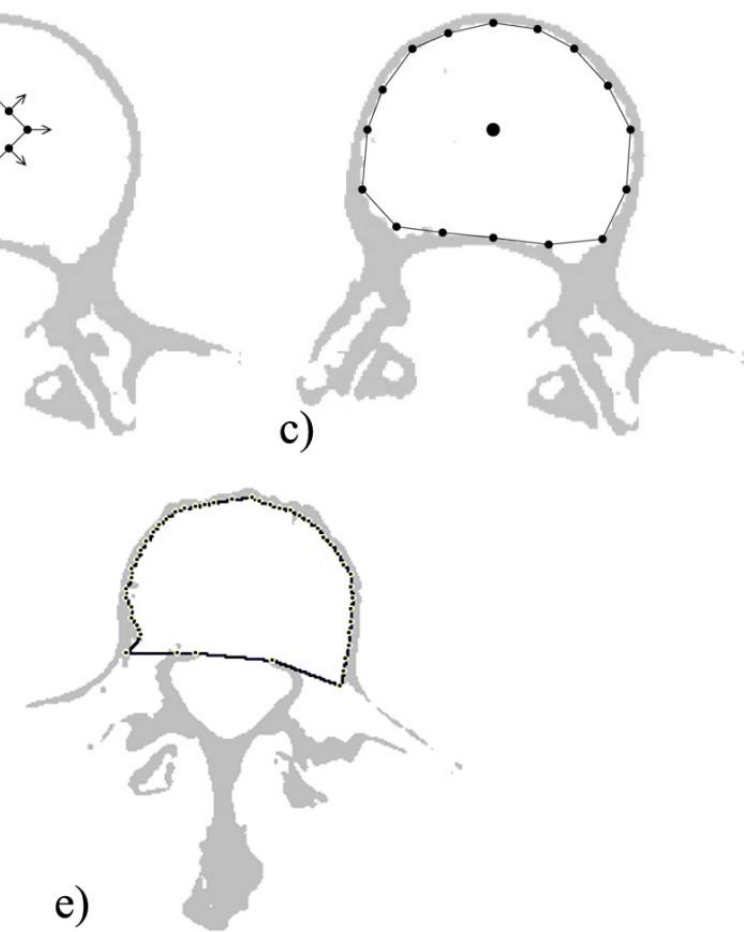

Fig. 3. Adaptive contour creation: a) Control points are placed at the starting point; b) Control points move in all directions and new control points are created; c) Control points stop at the cortical bone; d) Control points that go through the holes are deleted; e) Created contours after the control points are deleted. 


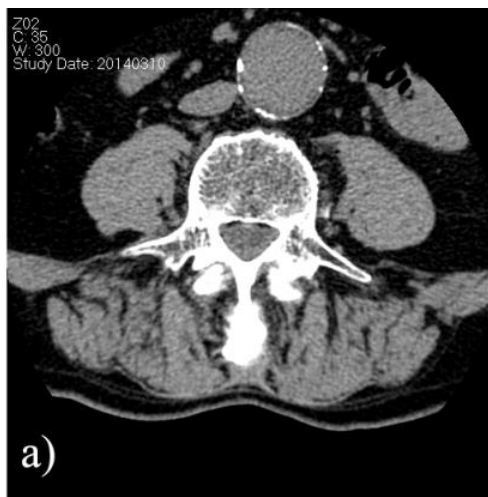

d)
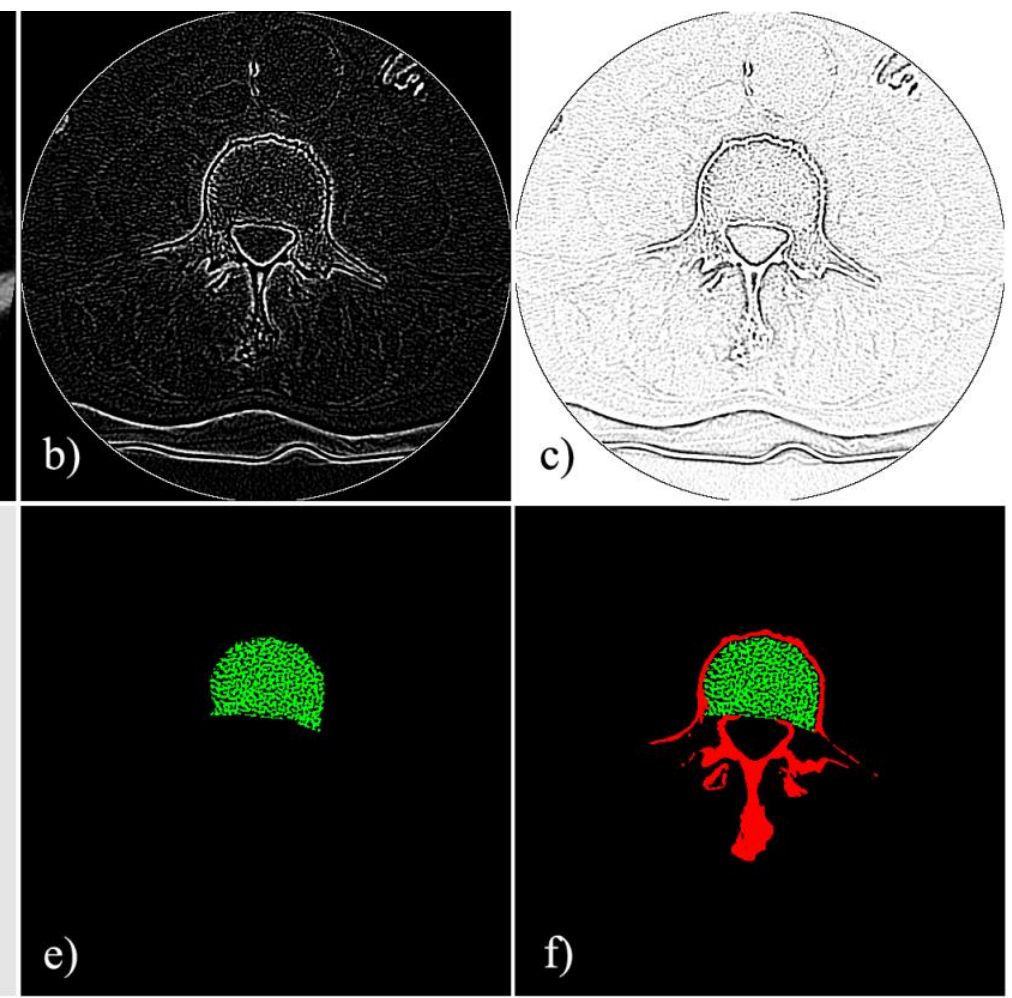

Fig. 4. Trabecular bone extraction. a) Original medical image; b) Laplace filter applied to the image; c) Inverse Laplace filter; d) Adaptive contour; e) Extracted trabecular bone; f) Extracted trabecular and cortical bones.

3. If the distance between the two neighboring control points becomes larger than 10 pixels, then a new control point is created between them, with a movement vector calculated as a normalized sum of two neighboring control point vectors (Fig. 3b)); A new control point is not created if either one of the neighboring points is in a stopped state.

4. The second and the third step is repeated until all control points stop moving (Fig. 3c));

5. The distances between all neighboring control points are calculated to find those control points that have gone out of the cortical bone. If the distance between the control points exceeds 20 pixels, then these control points are selected (Fig. 3d));

6. All control points that are located between the selected control points are deleted (Fig. 3e)).

When the adaptive contour is finally created, it is used to extract the trabecular bone. This is done by applying the Laplace filter to the region inside the adaptive contour. This last step is mostly the same for the medical images of long bones and vertebra, with the only exception being, that in the case of long bones the algorithm is repeated several times to extract the trabecular bone from all bones. This algorithm contains the following steps:

1. The Laplace filter is applied to the medical image, that detects changes in density and assigns values to pixels in the range from 0 to 255 (Fig. 4b)) and Fig. 4c));

2. All pixels that are located inside the adaptive contour are selected by using the region growing algorithm [15] (Fig. 4e));
3. Those pixels with a Laplace value larger than $10 \%$ of maximal value (25) are removed from the selection.

\section{Bone structure visualization}

$3 \mathrm{D}$ visualization of bone structure or any other medical object is a significant aspect of medical image analysis and research. Automatic analysis and visualization of medical image data, that was acquired using Computed Tomography or Magnetic Resonance imaging, is very helpful in medical studies and clinical practice. The possibility to visualize the orientation, position and size of medical objects is useful for researchers and doctors.

To create a 3D model of a medical object it is necessary to extract this object from the medical image, by using medical image segmentation methods. Then a 3D model of a medical object can be created by using several methods. This method uses the marching cube [16] algorithm to create a 3D model surface. This algorithm allows to create a 3D model of a complex structure, which could have holes and consist of several parts.

One of the main disadvantages of the marching cube algorithm is that, the surface of the 3D model, which has been created using this algorithm, contains a distinct aliasing effect between the medical image slice, which can be seen in Fig. 5c). To increase the surface quality of the model, the proposed method uses a surface smoothing algorithm.

The surface of a 3D model is described with vertexes, which are interconnected into triangles. The main point of the smoothing algorithm is to slightly move these vertexes, to smooth the sharp edges, which might appear between the triangles. 
a)
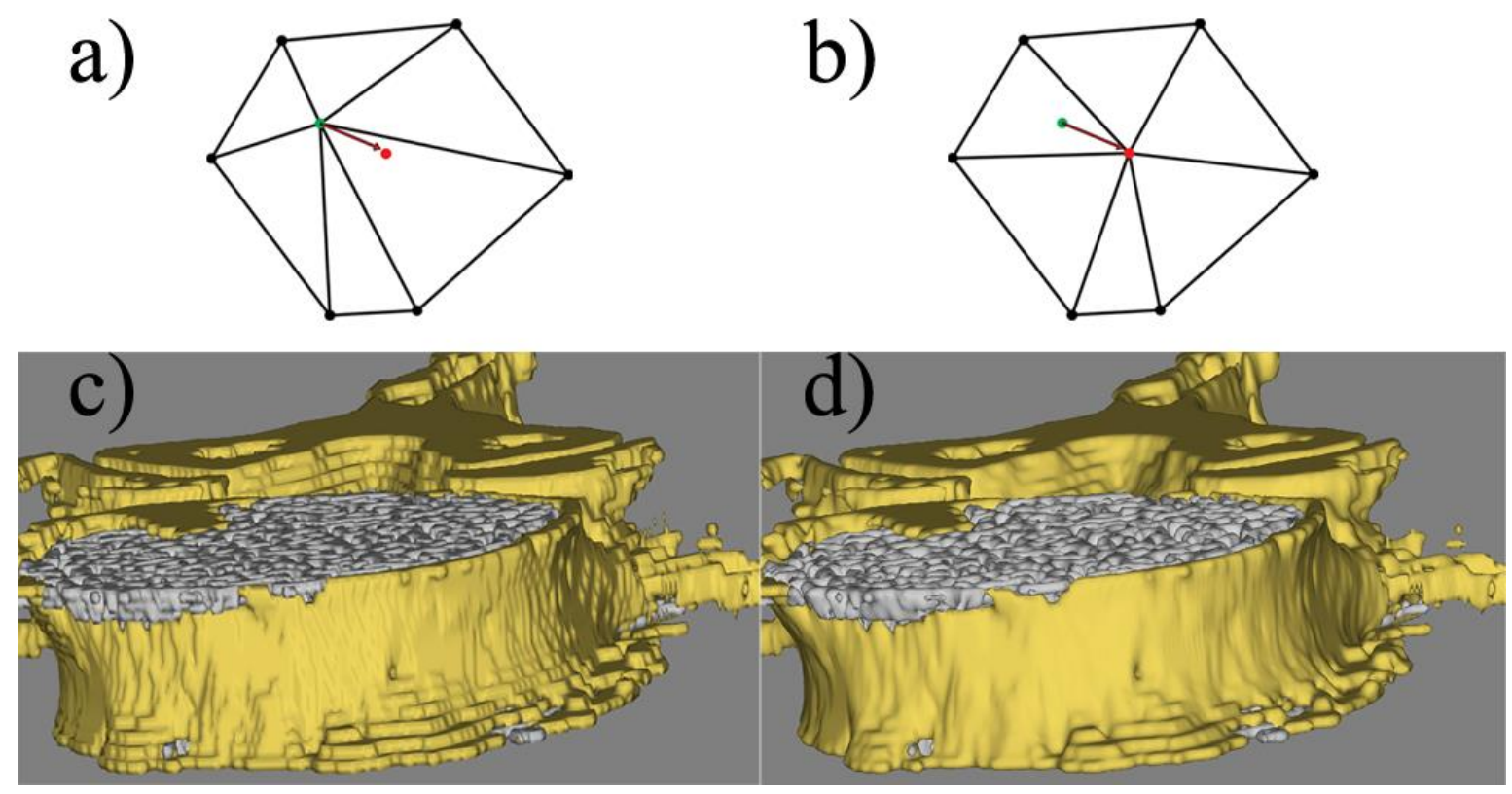

Fig. 5. a) Oiginal vertex(green), is replaced with a new one (red). b) Connections between the vertexes are preserved. c) 3D model of a vertebra, created using the marching cubes algorithm. d) The same 3D model after applying the smoothing algorithm.

The smoothing algorithm contains the following steps:

1. Look for all the vertexes that are connected to the selected vertex;

2. New vertex coordinates are calculated so that they are located in the middle between all the connected vertexes;

3. A new vertex is placed in the calculated coordinates;

4. The first three steps are repeated for all vertexes of the 3D model;

5. The second $3 \mathrm{D}$ model is created using all the new vertexes, while preserving the connections between the vertexes of the original 3D model.

The visualization of cortical bone thickness, allows to show the thickness of the bone in three dimensions, which could help the doctors to better evaluate the state of the bone. To create the 3D model, which could display the bone thickness, it is necessary to process the medical images to create the cortical bone thickness map.

The first step in creating the cortical bone thickness map, is applying the distance transform function [17] to the medical image with an extracted cortical bone. The distance transform function assigns a value to each pixel of the cortical bone. This value is equal to the distance from each cortical bone pixel to the nearest pixel, which does not contain the cortical bone (background). A simple example of the distance transform function is shown in Fig. 6.

An example of applying the distance transform function on real cortical bone medical image is shown in Fig. 7a), where the distance transform value is represented by the pixel brightness (the brighter the pixel, the greater the value).

By applying the distance transform function on the medical image a distance transform map is created, which is later used to create the cortical bone thickness map. The cortical bone thickness map creating algorithm contains the following steps:
1. Look for and select a pixel, that is located on the edge of the cortical bone (distance transform value is 1 );

2. Search radius is set to 1 pixel;

3. Look for the cortical bone pixels around the selected pixel inside the search radius, whose distance transform value is greater than that of the selected pixel;

4. If a pixel is found with a distance transform value greater than that of the selected pixel, then this value is assigned to the selected pixel and the search radius is increased.

5. Steps 3 and 4 are repeated until no pixel is found inside the search radius with a distance transform value greater than that of the selected pixel;

6. Steps 3, 4 and 5 are repeated until all the cortical bone edge pixels are assigned a new value, this value then becomes the bone thickness value;

7. Look for and select the cortical bone pixel which has at least one neighboring pixel with an assigned bone thickness value;

8. A bone thickness value is assigned to the selected pixel which is equal to the average bone thickness value of all the neighboring pixels;

9. Steps 7 and 8 are repeated until all cortical bone pixels are assigned a bone thickness value.

\begin{tabular}{|l|l|l|l|l|l|l|}
\hline 0 & 0 & 0 & 0 & 0 & 0 & 0 \\
\hline 0 & 1 & 1 & 1 & 1 & 1 & 0 \\
\hline 0 & 1 & 1 & 1 & 1 & 1 & 0 \\
\hline 0 & 1 & 1 & 1 & 1 & 1 & 0 \\
\hline 0 & 1 & 1 & 1 & 1 & 1 & 0 \\
\hline 0 & 1 & 1 & 1 & 1 & 1 & 0 \\
\hline 0 & 0 & 0 & 0 & 0 & 0 & 0 \\
\hline
\end{tabular}$\quad \longrightarrow \quad$\begin{tabular}{|l|l|l|l|l|l|l|}
0 & 0 & 0 & 0 & 0 & 0 & 0 \\
\hline 0 & 1 & 1 & 1 & 1 & 1 & 0 \\
\hline 0 & 1 & 2 & 2 & 2 & 1 & 0 \\
\hline 0 & 1 & 2 & 3 & 2 & 1 & 0 \\
\hline 0 & 1 & 2 & 2 & 2 & 1 & 0 \\
\hline 0 & 1 & 1 & 1 & 1 & 1 & 0 \\
\hline 0 & 0 & 0 & 0 & 0 & 0 & 0 \\
\hline
\end{tabular}

Fig. 6. Simple example of the distance transform function. Left: numbers represent different pixels of the medical image $(0$ - background, 1 - cortical bone). Right: numbers show the value of the distance transform function. 


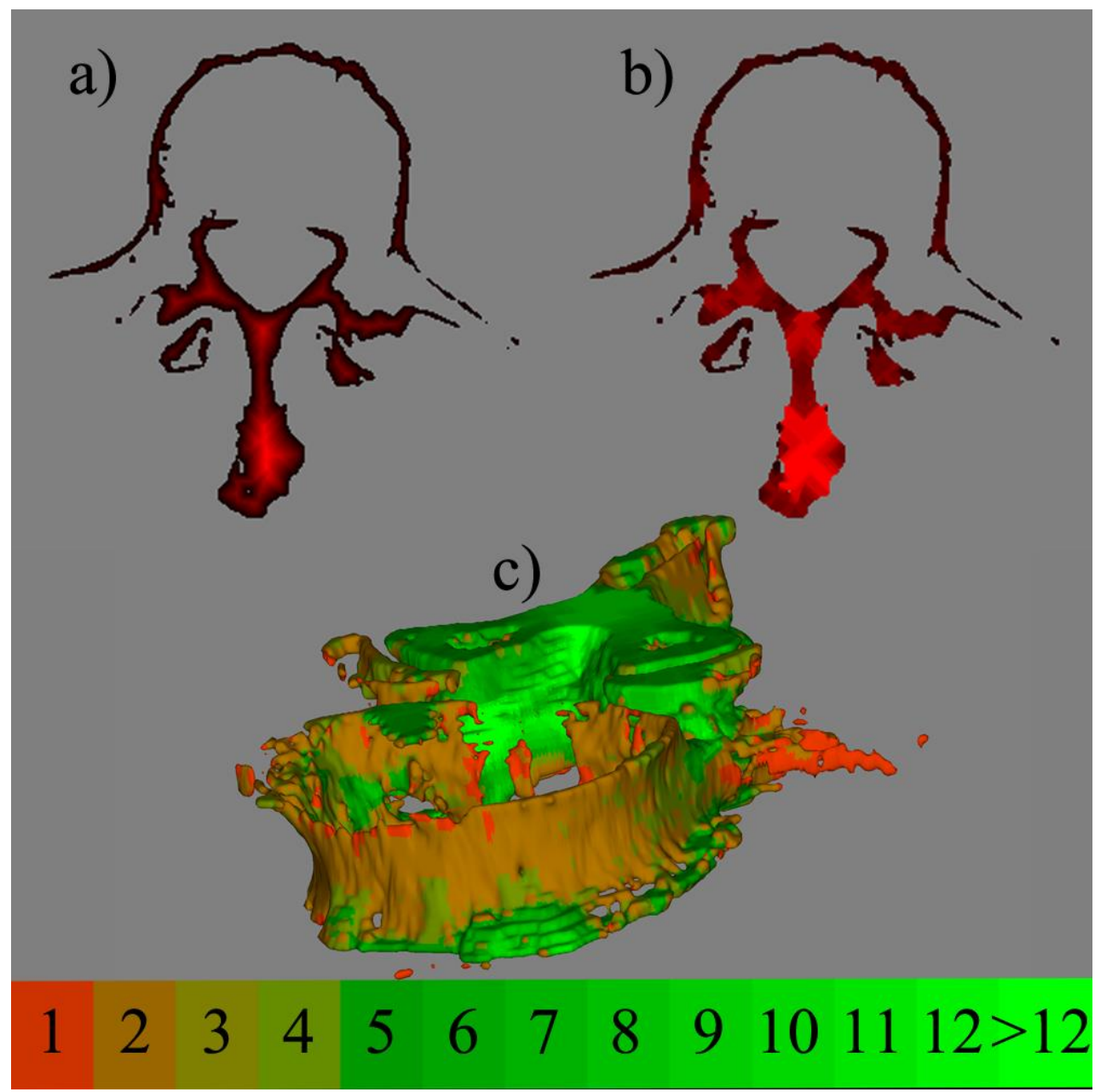

Fig. 7. a) Cortical bone distance transform map. b) Cortical bone thickness map. c) 3D model of cortical bone of a vertebra, where the thickness of the cortical bone is displayed with different colors (the color scale is shown below where numbers represent thickness in pixels).

An example of a cortical bone thickness map is shown in Fig. 7b). This map is implemented into the marching cube algorithm, which is used to create the $3 \mathrm{D}$ model of the cortical bone. When creating the 3D model, each marching cube looks at the thickness values of pixels, which are located inside each cube. Each cube is assigned a thickness value, which is equal to the average thickness of all the pixels that are located inside the cube. After a 3D surface is being created inside each marching cube, a thickness value is assigned to the surface polygons inside the cube, which equals the thickness value of the cube. When the 3D model is visualized, the polygons are displayed in different colors, depending on polygon thickness value (Fig. 7c)).

\section{CONCLUSION}

The proposed method allows to visualize the bone structure by creating a separate 3D model of cortical bone and of trabecular bone and it also allows to visualize the cortical bone thickness by displaying it in different colors on a 3D model.

The main advantage of the proposed method is that it is fully automatic, the only time it might need an operator input is if the operator chooses to change the radiodensity threshold which is used to extract the cortical bone.
The proposed method could be used when analyzing the medical images of patients with osteoporosis, where it is necessary to analyze changes in the microstructure of the bone. This method could also be used in studies, where it is necessary to analyze a large amount of medical images.

\section{REFERENCES}

[1] J. E. Adams, "Dual-Energy X-Ray Absorptiometry," Radiology of Osteoporosis, Medical Radiology, Springer Berlin, 2008, pp. 105-124.

[2] P. Ammann, R. Rizzoli, "Bone strength and its determinants," Osteoporosis International, 2003, vol. 14, no. 3, pp. 13-18.

[3] B. R. McCreadie, S. A. Goldstein, "Biomechanics of Fracture: Is Bone Mineral Density Sufficient to Assess Risk?" Journal of bone and mineral research, 2000, vol. 15, pp. 2305-2308. http://dx.doi.org/10.1359/jbmr.2000.15.12.2305

[4] F. W. Wehrli, P. K. Saha, B. R. Gomberg et al. "Role of magnetic resonance for assessing structure and function of trabecular bone," Topics in Magnetic Resonance Imaging, 2002, vol. 13, pp. 335-355. http://dx.doi.org/10.1097/00002142-200210000-00005

[5] T. Hildebrand, A. Laib, R. Muller et al. "Direct threedimensional morphometric analysis of human cancellous bone: microstructural data from spine, femur, iliac crest, and calcaneus," Journal of bone and mineral research, 1999, vol. 14, pp. 1167-1174. http://dx.doi.org/10.1359/jbmr.1999.14.7.1167

[6] R. Krug, A. J. Burghardt, S. Majumdar, T. M. Link, "A High-Resolution Imaging Techniques for the Assessment of Osteoporosis," Radiologic Clinics of North America, 2010, vol. 48, pp. 601-621. http://dx.doi.org/10.1016/j.rcl.2010.02.015 
[7] A. J. Burghardt, T. M. Link, S. Majumdar, "High-resolution Computed Tomography for Clinical Imaging of Bone Microarchitecture," Clinical orthopaedics and related research, 2011, vol. 469, pp. 2179-2193. http://dx.doi.org/10.1007/s11999-010-1766-x

[8] S. Boutroy, M. L. Bouxsein, F. Munoz, P. D. Delmas, "In vivo assessment of trabecular bone microarchitecture by highresolution peripheral quantitative computed tomography," The Journal of clinical endocrinology and metabolism, 2005, vol. 90, pp. 6508-6515. http://dx.doi.org/10.1210/jc.2005-1258

[9] H. R. Buie, G. M. Campbell, R. J. Klinck et al. "Automatic segmentation of cortical and trabecular compartments based on a dual threshold technique for in vivo micro-CT bone analysis," Bone, 2007, vol. 41, pp. 505-515. http://dx.doi.org/10.1016/j.bone.2007.07.007

[10] G. N. Hounsfield, "Computed medical imaging," Medical physics, 1980, vol. 7, pp. 283-290. http://dx.doi.org/10.1118/1.594709

[11] B. Hyun, D. C. Newitt, S. Majumdar, "Assessment of cortical bone structure using high-resolution magnetic resonance imaging," Proceedings 13th Scientific Meeting, International Society for Magnetic Resonance in Medicine, Miami, 7-13 May, 2005.

[12] J. T. Bushberg, J. A. Seibert, Jr. E. M. Leidholdt, J. M. Boone, The Essential Physics of Medical Imaging, 2nd ed., Lippincott Williams \& Wilkins, 2001, p. 933.

[13] P. Suetens, Fundamentals of Medical Imaging, 2nd ed., Cambridge University Press, 2009, p. 261. http://dx.doi.org/10.1017/CBO9780511596803

[14] D. C. Newitt, B. Van Rietbergen, S. Majumdar, "Processing and analysis of in vivo high-resolution MR images of trabecular bone for longitudinal studies: reproducibility of structural measures and microfinite element analysis derived mechanical properties," Osteoporosis International, 2002, vol. 13, pp. 278-287. http://dx.doi.org/10.1007/s001980200027
[15] W. K. Pratt, Digital Image Processing: PIKS Scientific Inside, 4th ed., Hoboken, New Jersey: John Wiley \& Sons, 2007, p. 782. http://dx.doi.org/10.1002/0470097434

[16] W. E. Lorensen, H. E. Cline, "Marching Cubes: a high resolution 3D surface reconstruction algorithm," Proceedings of the 14th Annual Conference on Computer Graphics and Interactive Techniques, SIGGRAPH, 1987, vol. 21, pp. 163-169.

[17] A. Jain, Fundamentals of Digital Image Processing, $1^{\text {st }}$ ed., New Jersey: Prentice-Hall, 1989, p. 565.

Mihails Kovalovs was born in Riga, Latvia, September 7, 1986. He is a $\mathrm{PhD}$ student at the Faculty of Computer Science and Information Technology, Riga Technical University.

He received the degree of Master of Technical Sciences from Riga Technical University in 2011.

E-mail: Mihails.Kovalovs@rtu.lv

Aleksandrs Glazs was born in Riga, Latvia, April 7, 1939. He is a Professor with the Faculty of Computer Science and Information Technology, Deputy-Director of the Institute of Computer Control, Automation and Computer Engineering and Head of Image Processing and Computer Graphics Division, Riga Technical University.

He received the Degree of Candidate of Technical Sciences from Riga Polytechnical Institute in 1971 and the Degree of Doctor of Technical Sciences (Dr. habil. sc. ing.) from the Russian Academy of Science in Moscow in 1992. He is the author of more than 100 scientific publications in different areas: pattern recognition, images processing, computer vision and computer graphics.

A. Glazs is a full member of the Baltic Informatization Academy.

Address: Meza Street 1, Riga LV-1048, Latvia.

E-mail: glaz@egle.cs.rtu.lv

\section{Mihails Koval̨ovs, Aleksandrs Glazs. Kaulu struktūras un biezuma 3D vizualizācija}

Šajā darbā tiek aprakstīta medicīnas attēlu segmentācijas metode, kur attêli tika iegūti ar datortomogrāfiju kaula struktūras trīsdimensiju modeḷa veidošanai. Šo pieeju var pielietot kaula struktūras analīzē, tā var būt noderīga ārstiem, kuri ārstē pacientus ar osteoporozi, un kad ir nepieciešams analizēt izmainas kaula struktūrā.

Lai izveidotu medicīnas objekta trīsdimensiju modeli, pirmajā gadījumā nepieciešams izdalīt šo objektu medicīnas attēlā, izmantojot segmentācijas metodes. Pašreiz jau ir daudzas medicīnas attēlu segmentācijas metodes, taču vairākums no tām ir pusautomātiskas, tāpēc ir nepieciešama operatora iejaukšanās segmentācijas procesā, kas palielinātu laiku, kas tika patērēts medicīnas attēla segmentācijai. Šajā darbā piedāvātā metode ir pilnīgi automātiska un tiek izmantots medicīnas attēls, kas iegūts ar parastas datortomogrāfijas palīdzību.

Piedāvātā metode sastāv no trim posmiem: pirmajā - medicīnas attēlā tiek izdalīts kortikālais kauls; otrajā - agrāk izdalītajā kortikālajā kaulā tiek veidots kontūrs, kurš adaptējas pie iekšèjās kortikālā kaula malas un šajā kontūrā tiek izdalīts trabekulārais kauls; trešajā posmā, izmantojot maršējošo kubu algoritmu, tiek veidots kortikālā un trabekulārā kaula trīsdimensiju modelis. Šajā darbā tiek aprakstīta arī trīsdimensiju virsmas nogludināšanas metode, kura tika iegūta, izmantojot maršējošo kubu algoritmu, kā arī kaula biezuma vizualizācijas metode.

\section{Михаил Ковалёв, Александр Глаз. ЗД визуализация структуры и толщины кости.}

В данной работе описывается метод сегментирования медицинских изображений, полученных с помощью компьютерной томографии, для создания трехмерной модели структуры кости. Данный метод может быть использован для анализа структуры кости, что может быть полезно для врачей лечащих пациентов с остеопорозом, где необходимо анализировать изменения в структуре кости.

Для создания трехмерной модели медицинского объекта, в первую очередь, необходимо выделить этот объект на медицинском изображении, используя методы сегментации. На данный момент уже существует множество методов сегментации медицинских изображений, но большинство этих методов являются полуавтоматическими, и требуют вмешательства оператора в процесс сегментации, что значительно увеличивает время, потраченное на сегментацию медицинского изображения. Предложенный в данной работе метод, является полностью автоматическим и использует медицинские изображения, полученные с помощью обычной компьютерной томографии.

Предложенный метод состоит из трех этапов. На первом этапе на медицинском изображении выделяется кортикальная кость. На втором этапе внутри ранее выделенной кортикальной кости создается контур, который адаптируется к внутренней стороне кортикальной кости, и внутри этого контура выделяется трабекулярная кость. На последнем этапе при помощи алгоритма марширующих кубов, создается трехмерная модель кортикальной и трабекулярной кости. В данной работе также описывается метод сглаживания трехмерной поверхности, полученной с помощью алгоритма марширующих кубов, а также метод визуализации толщины кости. 